\title{
MITOS KECANTIKAN (Ketegangan Citra Perempuan di Bawah Budaya Televisi)
}

\author{
Mardian Sulistyati \\ UIN Syarif Hidayatullah Jakarta, dianmakruf@gmail.com
}

Diterima: 30 Januari 2019

Direvisi: 2 Mei 2019

Diterbitkan: 30 Juni 2019

\begin{abstract}
The competition of the television industry in Indonesia creates open spaces for the image of women with the aesthetic standards they create. Television is now no longer just a medium of entertainment but as an ideal female image construction. Beautiful rules are no longer focused on women-only programs but have penetrated the entertainment, religious, reportage, politics, sports, economy, and crime segments. This research is to answer the problem of women's image presented on television, the influence and response are generated; also, the strategies in managing their identity. Applicatively, this research applies the Identity Management Theory pioneered by William R. Cupach and Tadasu Todd Imahori. This theory is used to dismantle the process of identity formed, maintained, and changed in a relationship. This study found several keywords that formulated the concept of managing women's self-identity. These keywords are: force dead/stiff, cornered/alienated; dilemma; and unstable for the context of cultural conflict, and approach; adjustments; and rejuvenation for the completion phase.
\end{abstract}

Keywords: Myths of beauty, identity, media.

\begin{abstract}
Abstrak
Iklim industri media pertelevisian di Indonesia yang ketat dengan persaingan, secara terbuka menampilkan perempuan-perempuan dengan standar cantik yang mereka ciptakan. Televisi kini bukan lagi sekadar media hiburan, melainkan secara meyakinkan dan terus-menerus membangun konstruksi citra perempuan ideal. Standar perempuan cantik tidak lagi berfokus pada acara-acara bersegmen perempuan saja, tetapi telah merambahi segmen hiburan, religius, reportase, politik, olahraga, ekonomi, hingga kriminal. Penelitian ini menjadi penting untuk menjawab persoalan citra perempuan dihadirkan di media televisi; pengaruh dan respon yang ditimbulkan baik dari dalam diri atau dari lingkungan sosial; hingga strategi yang perempuan gunakan dalam mengorganisir diri. Secara aplikatif, penelitian ini menerapkan Identity Management Theory yang dipelopori oleh William R. Cupach dan Tadasu Todd Imahori. Teori ini digunakan untuk membongkar proses identitas terbentuk, terjaga, dan berubah dalam suatu hubungan. Sesuai dengan tradisi yang membentuknya yaitu sosiologis, teori ini bekerja pada konteks pertentangan budaya. Penelitian ini menemukan sejumlah kata kunci yang menjadi rumusan konsep dalam pengelolaan identitas diri perempuan. Kata kunci tersebut adalah: mati gaya/kaku; tersudutkan/teralienasi; dilema; dan labil untuk konteks pertentangan budaya, serta pendekatan (PDKT); penyesuaian; dan peremajaan untuk fase penyelesaian.
\end{abstract}

Kata Kunci: Mitos kecantikan, identitas, media. 


\section{PENDAHULUAN}

"In the past the virtual was intended to become actual: actuality was its destination. Today the function of the virtual is to proscribe the actual."1

Reformasi seperti yang dijagokan banyak pihak, menawarkan ragam kebebasan, salah satunya kebebasan media dan informasi. Namun pada titik inilah masalah yang sebenarnya muncul. Perkembangan media yang tanpa batas dewasa ini mesti diakui memunculkan isu-isu problematik baik secara sosial maupun kultural.

Dalam kaca mata ilmu komunikasi, problem itu mencakup di antaranya tanda-penanda, citrapencitraan, informasi, pemaknaan makna, hingga persoalan bagaimana informasi itu pada akhirnya membentuk persepsi, pemahaman, hingga nilai-nilai etis (dan kebenaran) dalam masyarakat. Terutama sekali, bagi dan terhadap perempuan. Alih-alih membawa angin segar perubahan, faktanya perempuan masih dan terus menjadi kekuatan mobilisasi untuk intervensi program dan kontrol sosial. $^{2}$

Polemik yang berkembang di seputar media, khususnya televisi, berkaitan erat dengan citra dan pendefinisian bagaimana perempuan seharusnya menampilkan diri. Iklim industri media pertelevisian di Indonesia yang ketat dengan persaingan, secara terbuka menampilkan perempuan-perempuan dengan standar cantik yang mereka ciptakan.

Pola kuasa media ini jelas tidak hanya terjadi di Indonesia. Perempuan-perempuan kulit hitam, kulit cokelat, termasuk kulit putih di Amerika juga dihadapkan pada pendefinisian kecantikan yang tidak adil. Bahwasanya, perempuan cantik adalah yang memiliki tubuh langsing, tinggi, lingkar

${ }^{1}$ Jean Baudrillard, The Vital Illusion (New York: Columbia University Press, 2000), 50.

2Penulis menemukan kesamaan antara mekanisme dan kontrol kuasa terhadap perempuan di era reformasi sekarang ini dengan konstruksi keperempuanan pada masa Orde Baru yang sepenuhnya dikontrol oleh negara. LihatJulia Suryakusuma, State Ibuism: The Social Construction of Womanhood pinggang yang kecil, berpayudara besar, berkulit putih, dan berambut pirang. Kesepakatan umum kecantikan ini kemudian menjadi pemicu fenomena eating disorder. Di setiap pagi, para perempuan bangun tidur dengan perasaan tidak menerima kondisi tubuhnya karena tidak memenuhi kriteria cantik tersebut. $^{3}$

Kini, standar itu tidak hanya ditemukan pada acara-acara bersegmen perempuan, tetapi telah merambahi segmen hiburan, religius, reportase, politik, olahraga, ekonomi, hingga kriminal. Dengan demikian suka tidak suka, apa yang menjadi nilai, pemikiran, dan perilaku perempuan, harus dijalani secara standar yang telah dipaksanormalkan dalam masyarakat.

Sebagai subjek yang rasional, Descartes menganjurkan sikap keraguan dengan tidak menerima mentah-mentah apa yang dihadapkan kepada manusia. Lantas bagaimana dengan perempuan? Semudah itukah? Simone de Beauvoir dengan tepat mendeskripsikan perihal the woman condition sebagai berikut:

"Woman is well placed to describe society, the world, the epoch to which she belongs, but only up to a certain point. Truly great works are those that put the world entirely in question. Now that woman doesn't do. She will critique, she will contest in detail; but to put the world completely into question one must feel oneself to be profoundly responsible for the world. Now she isn't to the extent that it's a world of men; she doesn't take charge in the way the great artist does. She doesn't radically contest the world, and this is why in the bistory of humanity there isn't a woman who has created a great religious orphilosophical system, or even a truly great ideology; for that, what's necessary is in some sense to do away with everythingthat's given [faire table rase de tout le donne] — as Descartes did away with all knowledge-and to start a fresh. Well,

in New Order Indonesia (Jakarta: Komunitas Bambu, 2011); Santi Indra Astuti, "Kuasa dan Kekerasan Perempuan dalam Sinetron Religius," Jurnal Perempuan 67 (2010): 37-53.

3Naomi Wolf, The Beauty Myth: How Images of Beauty Are Used Against Women (New York: HarperCollins Publisher, 2002), 1-2, https://doi.org/10.5860/ choice.29-3031. 
woman, by reason of her condition, isn't in a position to do that."

Tampaklah bahwa konsep manusia (laki-laki) Descartes dimaknai oleh Beauvoir sebagai yang memiliki kekuasaan untuk menyelesaikan segala hal, dan memiliki keraguan atas hal yang datang kepadanya. Namun tidak demikian bagi perempuan. Perempuan ada karena ia didefinisikan sebagai perempuan oleh masyarakat, yang dengan kata lain, perempuan diragukan.

Bukan hal mustahil tentu saja, jika televisi turut menentukan pengontrolan identitas perempuan. Begitu pula tarik-menarik antara citra televisi dengan konstruksi masyarakat atas perempuan. Sebab ketika perempuan dikonstruksi untuk hidup sesuai dengan definisi dan penilaian masyarakat, maka televisi adalah salah satu variabel yang paling bertanggung jawab sebab perannya dalam menyajikan citra-semu sosial masyarakat.

Sederet kasus masih bisa dibentangkan dan tentu saja diperdebatkan dan dikaji secara kritis: Bagaimana citra perempuan dihadirkan di media televisi sebagai mitos? Adakah pengaruh yang ditimbulkan, baik dari dalam diri atau dari lingkungan sosial perempuan? Adakah terjadi penolakan dalam diri perempuan atas citra tersebut? Lantas, apa strategi yang mereka (perempuan) gunakan dalam mengorganisir diri?

Dengan berpayungkan teori-teori komunikasi, tulisan ini hendak membongkar proses pengelolaan identitas pada diri perempuan-yang mana selama ini kerap terdistorsi. Entah, bila pada akhirnya terbukti bahwa media memang telah mengkonstruksi perempuan yang dalam istilah Haig A. Bosmajian sebagai warga negara kelas dua (the

${ }^{4}$ Nancy Bauer, Simone de Beauvoir, Philosophy \& Feminism (New York: Columbia University Press, 2001), 65.

${ }^{5}$ Simone de Beauvoir, The Second Sex (New York: Vintage Books, 2010).

'Stephen W. Littlejohn dan Karen A. Foss, Theories of Human Communication (Canada: Thomson Learning Academic Resource Center, 2008), 197-214. second-class citizen), maka ini akan semakin menegaskan kekhawatiran Beauvoir bahwa perempuan adalah the second sex. ${ }^{5}$

\section{KERANGKA TEORI}

Dalam ilmu komunikasi, terutama berteraskan pada konsep Stephen W. Littlejohn dan Karen A. Foss dalam bukunya Theories of Human Communication, terdapat empat tradisi keilmuan yang berbicara tentang "Hubungan" (the relationship).

Keempat teori tersebut adalah: Pertama, Tradisi Sibernetika yang berfokus pada pola-pola interaksi dalam suatu hubungan. Kedua, Tradisi Sosiopsikologis yang berfokus pada perilaku interpersonal atau karakteristik individu dalam suatu hubungan. Ketiga, Tradisi Sosiokultural. Tradisi ini berfokus pada pembentukan makna dan pengaturan proses hubungan. Kemudian keempat, yakni Tradisi Fenomenologis, tradisi yang fokus pada aspek internal dan pengalaman sadar individu sebagai data utama memahami realitas. ${ }^{6}$

Tulisan ini, dalam penarapannya berpayung pada tradisi sosiokultural. Sebagaimana dipaparkan Littlejohn dan Foss, tradisi sosiokultural merupakan perpanjangan tangan dari tradisi sosiopsikologis dengan memperluas karya Mary Anne Fitzpatrick tentang hubungan keluarga. ${ }^{7}$ Proses perpanjangan ini lebih menekankan proses bagaimana makna terbentuk serta bagaimana proses suatu hubungan diatur.

Hal pertama yang menjadi fokus pengenalan awal tradisi sosiokutural-sekaligus konsentrasi tulisan ini-adalah pengelolaan identitas. Identitas yang dimaksud tentu tidak terbatas pada pelaku

${ }^{7}$ Sederhananya, teori mengenai hubungan keluarga di bawah asuhan Fitzpatrick ini bekerja berlandaskan cara-cara anggota keluarga sebagai individu yang memandang keluarga itu sendiri. Lihat Mary Anne Fitzpatrick, Between Husbands and Wives: Communication in Marriage (Newbury Park, CA: SAGE Publications, 1988). Bandingkan dengan Littlejohn dan Foss, Theories of Human Communication, 199-204. 
komunikasi tetapi juga pada hubungan yang menyertainya.

Teori Pengelolaan Identitas yang dikembangkan Tadasu Todd Imahori dan William R. Cupach contohnya, berusaha membuktikan bagaimana suatu identitas tertentu, terjaga, dan berubah. $^{8}$ Teori pengelolaan identitas banyak menjelaskan perkara perubahan budaya_sebagai pertentangan budaya-yang menempati posisi krusial dalam suatu hubungan. perbedaan budayasebagai pertentangan budaya-yang menempati posisi krusial dalam suatu hubungan. ${ }^{9}$

Pertentangan budaya yang dimaksud dapat terjadi melalui empat cara, yaitu: identity freezing, nonsupportproblem, self-other dialectic, dan positive-negative face dialectic.

Pertama, salah satu pihak dari suatu relasi akan terbatasi sehingga tersudutkan ke dalam bentukbentuk budaya tertentu. Biasanya, pihak ini kemudian tidak diterima sebagai identitas yang utuh dan kompleks. Suatu kecenderungan yang dianggap "lazim" terjadi pada tahap awal sebuah hubungan beda budaya. Situasi seperti ini lumrah diatasi dengan cara menunjukkan aspek positif budaya sendiri sebagai bentuk dukungan atas identitas diri. Cupach dan Imahori melabeli pola pertama ini sebagai identity free $\boldsymbol{z}$ ing (kebekuan identitas).

Kedua, ada kalanya kedua belah pihak menemukan kondisi/fakta bahwa nilai-nilai budaya mereka diabaikan, atau yang diistilahkan sebagai persoalan non-support problem (non-dukungan). Situasi demikian seringkali dianggap sebagai satu tanda ancaman dan kemarahan

Ketiga, merupakan masalah yang kerap dialami dalam negosiasi identitas diri, yakni tekanan

${ }^{8}$ Littlejohn dan Foss, Theories of Human Communication, 204; Tadasu Todd Imahori dan William R. Cupach, "Identity Management Theory," in Theorizing About Intercultural Communication, ed. oleh William B. Gudykunst (US, Portland: Ringgold Inc., 2005), 195-210.

Untuk lebih memahami bentuk pertentangan budaya di dalam pengelolaan identitas, Littlejohn dan Foss menganalogikan sebuah pernikahan antarbudaya antara seorang istri dan dilema antara mendukung rupa/budaya sendiri atau rupa/budaya lain. Problem inilah yang dinamakan sebagai self-other face dialectic. Situasi ini terjadi manakala seseorang ingin mendukung identitas budaya lain, namun pada saat yang bersamaan juga ingin menonjolkan budaya sendiri/asal. Untuk menonjolkan atau mendukung budaya yang satu, seseorang (dituntut) akan terus menyangkal budaya yang lain.

Keempat, merupakan saat yang mana kedua belah pihak mengalami situasi tekanan antara ingin menegaskan nilai budaya, namun tanpa menghalangi atau membatasi budaya lain. Situasi ini disebut dengan positive-negative face dialectic (dialektis rupa positif negatif).

Sejatinya, pengelolaan identitas tidak pernah berakhir. Hanya saja setiap individu atau pasangan memiliki cara yang berbeda pada tahap hubungan yang berbeda. Secara khusus, Cupach dan Imahori menyebut tiga tahapan hubungan guna menghadapi pertentangan budaya-yaitu empat poin yang telah dibahas sebelum ini-dengan trial, emmeshment, dan renegotiation.

Pertama, dalam proses trial (percobaan), pasangan hanya menelusuri perbedaan dan identitas budaya yang diperlukan atau diinginkan untuk hubungan mereka saja. Perbedaan budaya biasanya menonjol pada titik ini. Tantangan terbesarnya adalah mencoba untuk menghindari nonsupport problem dan freezing identity, dan di saat yang sama tetap berusaha mengatur self-other face dialectic dan positive-negative face dialectic. Dengan kata lain, pasangan akan menghindari semua kesalahan yang mungkin terjadi dalam menangani identitas budaya satu sama lain.

asli Amerika yang besar di tempat penampungan dengan seorang suami Inggris yang berasal dari New York City yang kakek neneknya adalah imigran dari Italia. Dalam kasus pernikahan tersebut, sangat mungkin kedua belah pihak menemukan ragam tantangan budaya-baik spiritual, agama, dan ritual keagamaan, ikatan dasar, musik dan tarian, peran orang tua, hingga perkembangan anak. lihat Littlejohn dan Foss, Theories of Human Communication, 204-5. 
Kedua, dalam tahap emmeshment (kecocokan), sebuah identitas hubungan tertentu akan muncul. Di sini, pasangan menemukan tingkat kenyamanan dalam diri mereka sebagai pasangan. Mereka berbagi aturan dan simbol yang dapat dipahami satu sama lain. Artinya, hubungan pada tahap ini lebih didominasi oleh interaksi interkultural dengan meminimalisir komunikasi interkultural. ${ }^{10}$

Ketiga, tahap renegotiation (negosiasi ulang). Pada tahap ini, seseorang akan melalui beragam masalah identitas antarpersonal, namun hal tersebut dapat diantisipasi dengan identitas-hubungan yang matang. Ada landasan kuat yang mendasari hubungan, yang dengannya perbedaan budaya menjadi lebih mudah diatasi. Perbedaan bahkan telah didefinisikan sebagai bagian dari hubungan, sehingga ada kerangka yang lebih besar untuk memahami perbedaan. Kondisi seperti ini diregenerasi secara berkala oleh kedua belah pihak. Sederhananya, perbedaan budaya sudah mampu dilihat sebagai elemen positif dari suatu hubungan.

\section{KERANGKA METODOLOGI}

Sebagaimana kerangka teori yang telah penulis paparkan, tulisan ini bersandar kepada teori pengelolaan identitas. Untuk lebih mudahnya, penulis membagi pengelolaan identitas ke dalam dua fase utama, yakni fase permasalahan dan fase penyelesaian. Fase permasalahan meliputi identity freezing, nonsupportproblem, self-other face dialectic, dan positive-negative face dialectic. Sedangkan fase penyelesaian meliputi trial, emmeshment, dan renegotiation.

Dari sini-merujuk kepada data terkait respon atas konstruksi citra perempuan ideal yang telah diselaraskan dengan kerangka teori, penulis memperoleh kata kunci-kata kunci sebagai konsep

${ }^{10}$ Littlejohn dan Foss melanjutkan dengan contoh, the Jewish-Christian couple's decision to have a Christmas tree with a star of David on top is one example of an agreement that might come come to characterize the enmeshment phase. Lihat Littlejohn dan Foss, 206. metodologis pengelolaan identitas dalam diri perempuan. Kata kunci tersebut adalah: mati gaya/kaku; tersudutkan/teralienasi; dilema; labil untuk fase permasalahan, dan pendekatan (PDKT); penyesuaian; peremajaan untuk fase penyelesaian. Semua istilah ini diperoleh dari hasil wawancara penulis terhadap 10 (sepuluh) responden perempuan.

\section{Pertama: Fase permasalaban}

Mati gaya atau juga dibahasakan dengan kaku, merupakan ungkapan yang menggambarkan kondisi seseorang (perempuan) yang terbatasi atau tersudutkan ke dalam model identitas atau citra ideal tertentu. Pada posisi ini, orang tersebut merasa dirinya tidak diterima sebagai identitas yang utuh dan kompleks atau "normal". Secara teoretis kondisi ini masuk ke dalam kategori identity freezing, atau kebekuan identitas.

Tak lama setelah mengalami identity freezing, biasanya seseorang akan mendapati (merasa) dirinya tersudutkan atau teralienasi. Suatu kondisi perasaan yang kerap memicu kecemasan dan bahkan kemarahan sang individu. Ia akan sangat merasa diabaikan oleh lingkungan sosialnya. Inilah yang penulis identifikasi ke dalam kategori nonsupport problem atau non-dukungan.

Berikutnya adalah dilema, istilah yang penulis gunakan untuk mewakili kategori self-otherface dialectic atau dialektika rupa sendiri dan orang lain. Seseorang, dalam konteks ini, dikatakan dilema karena pada saat bersamaan ia dituntut untuk mengedepankan identitas/budaya dirinya sendiri dan identitas/budaya orang lain. Hampir semua kasus membuktikan, untuk menonjolkan atau mendukung budaya yang satu, seseorang (dituntut) akan terus menyangkal budaya yang lain. ${ }^{11}$

${ }^{11}$ Dalam konteks ini, Littlejohn dan Foss mengibaratkan dengan fakta, "An African-American man we know is married to a Chinese noman. He is fluent in Mandarin, so they can speak easily to each other, but she knows very little English. Thus, when they are in the United States, interacting with his friends, she refuses to 
Fase permasalahan yang terakhir versi Cupach dan Imahori adalah positive-negative face dialectic atau dialektis rupa positif negatif. Dalam banyak kasus, labil merupakan istilah yang pa-ling mampu mewakili kondisi positive-negative face dialectic ini. Labil adalah saat yang mana seseorang mengalami tekanan antara ingin menegaskan nilai budaya sendiri, namun tanpa menghalangi atau membatasi budaya lawan hubungannya.

\section{Kedua: Fase penyelesaian}

Pendekatan (PDKT) atau dalam istilah Cupach dan Imahori disebut sebagai trial (percobaan), yakni tahap meraba-raba, menelusuri perbedaan dan identitas budaya yang diperlukan atau diinginkan saja. Tantangan terbesar PDKT adalah menghindari freezing identity (mati gaya, kekakuan) dan nonsupportproblem (perasaan teralienasi dan sepi), juga di saat yang sama tetap berusaha mengatur selfother face dialectic (dilema) dan positive-negative face dialectic (kelabilan). Sederhananya, seseorang dituntut sebisa mungkin menghindari semua kesalahan yang rawan terjadi dalam menangani identitas satu sama lain.

Penyesuaian, adalah fase di kala seseorang menemukan kenyamanan dalam dirinya. Ia telah mampu menerima (menggunakan) simbol atau aturan budaya lain. Pada tahap ini, hubungan lebih didominasi oleh interaksi dibanding komunikasi. Secara teoretis, penyesuaian berarti emmeshment (kecocokan).

Selanjutnya adalah peremajaan. Setelah melalui tahap penyesuaian, seseorang akan menghadapi beragam masalah identitas antarpersonal. Di sinilah kemampuan peremajaan—atau yang dalam bahasa teoretisnya disebut renegotiation (negosiasi ulang)—dibutuhkan. Penulis mendapati fase akhir ini sebagai fase pematangan lagi dan lagi atas konsep-konsep diri dan landasan dalam

speak. English and wants him to translate everything into Mandarin for her. In this case, he cannot easily assert his own identity-U.S., black- hubungan, yang pada akhirnya akan mengokohkan sang individu dan hubungan itu sendiri.

Istilah-istilah tersebut, penulis dapatkan dari hasil wawancara mendalam (in-depth interview), yang juga merupakan istilah pergaulan sehari-hari di dalam lingkungan perempuan untuk mewakili situasi personal mereka pada umumnya. Penulis melakukan wawancara personal kepada sepuluh orang responden perempuan dengan kisaran usia 17 s.d. 25 tahun. Kesepuluh responden dipilih berdasarkan ketertarikan dan memiliki alokasi waktu yang lebih dan konsisten untuk menonton televisi (sinetron pendek televisi (ftv), infotainment, dan acara lifestyle) setiap harinya.

\section{STUDI KASUS}

Perkembangan media televisi dan segala sesuatu yang disuguhkan (sinetron pendek televisi (ftv), periklanan, infotainment, fashion show, dan sebagainya), mempunyai hubungan timbal balik dengan perubahan pada masyarakat. Di dalam masyarakat berkembang berbagai logika baru yang ditampilkan media televisi dalam bentuk tanda dan citra. Secara mendasar, logika baru inilah yang membentuk definisi umum atas kecantikan, yang selanjutnya mengubah model hubungan antar dan interpersonal.

Sebagai contoh, berikut kutipan iklan produk yang berupaya merepresentaskan perempuan cantik dengan tubuh yang langsing, yakni iklan WRP Body Shape:

"WRP Boudy Shape. Burn Fat, Get Shape. When Slim is not enoughy SEXY does Matter! Dengan pinggang langsing sediakala, saya makin pede, suami pun turut bangga (Lybya, 32 th, ibu rumah tangga). Siapa sih wanita yang nggak ingin bertubuh langsing? Bukan khawatirsuami nggak sayang lagi gara-gara tubuh melar lho, tapi kayaknya dengan bertubuh ideal, kita jadilebih nyaman dan pede.

and support hers at the same time because be is busy translating for her." Lihat Littlejohn dan Foss, 206. 
Masalahnya sesudah menikah, berat badanku melonjak naik dan tentu saja pinggang yang ramping pun menghilang tertutup lemak. Akhirnya, kuputuskan ikut kompetisi WRP Cheongsam Challenge. Hasilnya pinggang rampingku pun kembali, bayangkan saja dari $78 \mathrm{~cm}$, lingkar pinggangku berkurang hingga $70 \mathrm{~cm}$. Dengan pinggang langsing sediakala, aku makin pede, suamiku pun turut bangga."

Kecantikan perempuan menjadi komoditas untuk menarik perhatian lawan jenis juga tampak pada iklan Oriflame berikut:

"Gaya Hollywood dengan warna memikat. Kilatan lampu kamera, para penonton yang ramai, dan gaya karpet merah-jadilah pusat perhatian dengan segala kepercayaan diri dan berkelas bersama produk-produk kami yang siap mentransformasi riasan mata Anda. Bebaskan jiwa selebriti Anda!"

Hal senada juga kita temui pada iklan produk pemutih Ponds Anti Aging. Pada iklan tersebut digambarkan seorang istri yang ketika masih berusia dua puluhan, hubungannya dengan sang suami sangat romantis. Sedangkan (kini) setelah usianya telah menginjak tiga puluh tahun ke atas, terlihat bahwa hubungannya dengan sang suami menjadi dingin. Pada scene berikutnya, sang istri bertemu pada temannya dan berkata, "Kamu masih terlihat muda di usia tiga puluh tahun," dan bisa ditebak, sang teman menawarkan produk Ponds-nya. Pada genre yang berbeda, iklan Ponds juga tampil dengan gambaran seorang gadis remaja yang tidak percaya diri karena dicueki oleh pria yang ia sukai. Namun setelah dia memakai Ponds, sang gadis akhirnya mendapatkan perhatian dari sang pria.

Secara implisit, iklan-iklan tersebut menunjukkan bahwa perempuan adalah objek untuk menyenangkan laki-laki (suami), bukan untuk kepentingan perempuan itu sendiri. Jika kita melihat berbagai tayangan di televisi-tidak hanya sebatas

12Lema "cermin" penulis pinjam dari Johnson dan Ferguson, yakni bermakna women's mirror. Lihat Karen Johnson dan Tom Ferguson, Karen Johnson dan Tom Ferguson, No iklan-maka akan terlihat bagaimana "perempuan cantik" menempati posisi sentral di sana.

Televisi memang menjadi terlalu menggoda untuk tidak ditonton. Apalagi Efeknya pun bermacam-macam, dan sering terlihat dari sebagian besar masyarakat yang meniru apa yang dicitrakan media, begitu saja mentah-mentah. Jika kaitannya tentang perempuan maka sudah pasti yang tampil selalu merujuk pada sosok yang cantik, seksi, genit, hingga berpakaian ketat-meski juga harus dicatat tidak selalu perempuan yang tampil di televisi seperti itu, ada juga yang memang memiliki "kualitas" seperti intelektualitas dan kapasitas lainnya.

\section{PENGARUH MITOS KECANTIKAN TERHADAP DIRI DAN LINGKUNGAN PEREMPUAN}

Untuk mengetahui sekaligus memahami ada atau tidaknya pengaruh mitos kecantikan televisi terhadap identitas perempuan, dapat dilihat dari gejala permasalahan yang umum mereka alami.

\section{Mati gaya / kaku (identity freezing)}

Citra perempuan yang diproduksi terusmenerus dan berkala melalui berbagai tayangan televisi, pada gilirannya seolah-olah menjadi realitas sehari-hari perempuan. Televisi pada fase ini, mampu bekerja layaknya "cermin" bagi perempuan. ${ }^{12}$ Ibarat bercermin, bagi sebagian perempuan akan mendapati standar atau cerminan yang tidak realistis. Hal inilah yang kemudian menyebabkan kecemasan dan berujung pada kondisi yang mati gaya.

\section{Alienasi (non-supportproblem)}

Dalam interaksi sosial, harus diakui bahwa bentuk fisik adalah hal pertama yang dinilai, termasuk perempuan. Penilaian terhadap kecerdasan intelektual dan kelebihan yang sifatnya dari dalam (inner beanty), tidak muncul di awal-awal interaksi.

TitleThursting Ourselves: The Sourcebook on Psychology for Women (New York: The Atlantic Montly Press, 1990). 
Budaya kesan pertama (first impression culture) di masyarakat kita menunjukkan bahwa lingkungan sering kali menilai seseorang berdasarkan kriteria luar, seperti tampilan fisik. ${ }^{13}$

Tubuh yang langsing dan proporsional akan mendapatkan respon positif dari masyarakat. Sementara itu, bagi perempuan yang kurang proporsional, akan mendapatkan respon negatif dan akan mendapati (merasa) dirinya tersudutkan atau teralienasi. Kondisi ini kemudian kerap memicu kecemasan dan bahkan kemarahan pe-rempuan. Ia akan sangat merasa diabaikan oleh lingkungan sosialnya. Beberapa kasus yang kerap dialami relawan penelitian ini adalah sebagai berikut:

"Saya punya satu sahabat baik di kantor (perusahaan advertising internasional). Bidang, divisi, dan jobdesc kami sama. Tapi yang selalu diajak bos bertemu klien itu teman saya, padahal itu adalah project saya, hanya karena saya tidak seputih dan selangsing teman saya." (AW, 32 tahun, Jakarta).

" $U$ dah enam bulan ini aku rutin konseling dan menjalani treatment. Aku depresi karena sejak SMA hingga kuliah selalu di-bully dan kena body shamed. Masuk dunia kerja tuntutan untuk kurus langsing semakin tinggi. Aku juga pernah diselingkuhi karena masalah ini. Akhinya aku semakin benci sama tubuhku dan sangat merusak kepercayaan diriku. Untungnya di salah satu acara kantor aku ketemu teman yang peduli tentang kesehatan mental dan merekomendasikan pskiater yang bagus." (GP, 28 tahun, Jakarta).

\section{PENOLAKAN PERSONAL TERHADAP MITOS KECANTIKAN}

\section{Dilema (self other dialectic)}

Ketika kriteria yang secara sosial dikondisikan sebagai tolak ukur idealisasi atas tubuh, akan turut mempengaruhi bagaimana sang pe-rempuan melakukan penilaian dan pemaknaan terhadap

\footnotetext{
13Melliana Anastasia S., Menjelajah Tubub: Perempuan dan
} Mitos Kecantikan (Yogyakarta: LKiS, 2006), 45. tubuhnya. Kemudian, perempuan dikondisikan untuk berada pada posisi pasif. Pihak media, dan lingkungan pergaulan pe-rempuanlah yang justru seolah menentukan identitas atas tubuhnya. Pada fase ini, perempuan mengalami dilema antara menegaskan identitas diri yang sesungguhnya, dan penilaian orang lain terhadapnya.

\section{Labil (positive-negative face dialectic)}

Pada fase ini, perempuan berada pada situasi emosi yang labil antara ingin menegaskan identitasnya sendiri, namun ia juga tidak ingin menutup rapat citra yang ditawarkan media terhadapnya.

\section{STRATEGI PENGELOLAAN DIRI}

\section{Pendekatan/PDKT (trial)}

Pada fase ini, perempuan mulai meraba-raba, dan memilah citra yang diperlukan atau diinginkan saja. Sang perempuan di sini berusaha sebisa mungkin mengubur dalam perasaan se-perti kekakuan, teralienasi, dan semacamnya, dan mulai membuka diri untuk menerima citra yang dianggap berkesesuaian dengan dirinya.

\section{Penyesuaian (emmeshment)}

Pada fase ini, sang perempuan telah menemukan kenyamanan dalam dirinya. Ia telah mampu menerima (menggunakan) simbol atau citra lain.

\section{Peremajaan (renegotiation)}

Pada tahap ini, perempuan telah sampai pada tahap identitas diri yang matang. Meski kemudian ia akan menghadapi beragam masalah identitas lain, namun itu akan mudah untuk dilewati.

\section{PENUTUP}

Di dalam media, terlihat perempuan dikondisikan untuk lebih terpesona kepada maknamakna simbolik dengan mencitrakan kecantikan 
ideal. Tanda dan citra pun digunakan secara aktif dan dinamis. Perempuan kemudian dengan mudah ditempatkan ke dalam struktur komunikasi yang dikonstruksi secara sosial. Citra tentu saja mempunyai peran yang sangat penting, sebagai pendefinisi relasi sosial dan alat untuk mengorganisir identitas: cantik, putih, tinggi, langsing.

Pada akhirnya, perempuan bukan lagi sebagai fakta biologis, melainkan fakta sosial yang telah dibentuk melalui produksi mitos atas tubuhnya. Televisi selaku media yang paling berpengaruh, telah meyakinkan banyak orang bahwa nilai kecantikan dominan sudah dikonfirmasi melalui ideologi dan mitologi, sehingga cukup sahih untuk ditampilkan di layarkaca.

\section{BIBLIOGRAFI}

Astuti, Santi Indra. "Kuasa dan Kekerasan Perempuan dalam Sinetron Religius." Jurnal Perempuan 67 (2010):37-53.

Baudrillard, Jean. The Vital Illusion. New York: Columbia University Press, 2000.

Bauer, Nancy. Simone de Beawvoir, Philosophy \& Feminism. New York: Columbia University Press, 2001.

Beauvoir, Simone de. The Second Sex. New York: Vintage Books, 2010.

Fitzpatrick, Mary Anne. Between Husbands and Wives: Communication in Marriage. Newbury Park, CA: SAGE Publications, 1988.

Imahori, Tadasu Todd, dan William R. Cupach. "Identity Management Theory." In Theorizing About Intercultural Communication, diedit oleh William B. Gudykunst, 195-210. US, Portland: Ringgold Inc., 2005.

Johnson, Karen, dan Tom Ferguson. No TitleThursting Ourselves: The Sourcebook on Psychology for Women. New York: The Atlantic Montly Press, 1990.

Littlejohn, Stephen W., dan Karen A. Foss. Theories of Human Communication. Canada: Thomson Learning Academic Resource Center, 2008.

S., Melliana Anastasia. Menjelajah Tubub: Perempuan dan Mitos Kecantikan. Yogyakarta: LKiS, 2006.

Suryakusuma, Julia. State Ibuism: The Social Construction of Womanhood in New Order Indonesia. Jakarta: Komunitas Bambu, 2011.

Wolf, Naomi. The Beauty Myth: How Images of Beauty Are Used Against Women. New York: HarperCollins Publisher, 2002. https://doi.org/10.5860/choice.29-3031. 